УДК: $7.033 .12 ; 7.033 .2 \ldots 7$

ББК: 85.113

A43

DOI: $10.18688 /$ aa188-9-74

Svetlana Mal'tseva

\title{
Historiography of the Morava Architecture: Controversial Points of the Study ${ }^{1}$
}

The triumphant reign of Prince Lazar Hrebeljanović (1371-1389) and his heirs was the period of the last and unusually brilliant cultural-political heyday of the medieval Serbian State [36, pp.1-11;37]. After the loss of independence in 1459, it was seen as the "golden era" of the national history. In the $19^{\text {th }}$ century, in the context of the liberation movement and the establishment of the modern state, the "revitalizing" of history and the idea of reviving Serbia’s former power of medieval epoch were essential elements in shaping national identity [43, pp. 70-71, 83-85, 93; 18; 1]. In that romantic environment, the works of historians, philologists, specialists, researchers, travelers, and enthusiastic amateurs laid the foundation for the study of the architecture of the Morava period, created the first descriptions of churches, found and published critical evidence $[23 ; 66 ; 29 ; 45 ; 51 ; 34$, pp. 154-157].

The more in-depth study of the monuments of Serbian medieval architecture starts in the mid- $19^{\text {th }}$ century along with more detailed descriptions, drawings, and engraved reproductions. At that time, the first attempts to classify Serbian monuments and to consider them in the context of European medieval architecture were made by primarily foreign researchers who brought on that soil their own methods and concepts. Some of them rushed to search on Serbian territories located literally between the East and the West for the confirmation of their hypotheses on the classification of the Romanesque and Gothic art; others did not separate the Serbian monuments from the Byzantine ones.

For instance, in the 1840s, a German art historian and an expert on Western European medieval architecture, F. Mertens, examined the Serbian monuments and divided them into two groups representing the two major "styles" or "schools" (these terms were used interchangeably by Mertens). The first group was classified as the monuments of the Nemanjić period influenced by the Western European tradition; the second group was identified as the monuments of the Moravian period influenced by the Byzantine tradition $[35 ; 4]$.

Later L.Förster, an Austrian architect and scientist, examined several Morava period churches and revealed more clearly their relationship to the Byzantine tradition, known to him mostly from the monuments of Greece $[16 ; 17]$. The most significant contribution to

1 The reported study was funded by Government Program of the Russian Federation "Development of science and technology" (2017-2018) with in Program of Fundamental Researches of Ministry of Construction, Housing and Utilities of the Russian Federation and Russian Academy of Architecture and Construction Sciences, the Research Project 1.2.32. / 1.2.46. 
the study of Serbian medieval architecture belongs to F. Kanitz, the German balkanist who in 1862 published the first in Europe monograph on Serbian medieval architecture accompanied by drawings and numerous illustrations $[19 ; 20]$. In his subsequent works he expands the scope of reviewed monuments, including the Morava school; in his posthumously published final monograph he considers as many as thirty five Morava churches [21]. Considering the need for a full-scale study of the monuments, F. Kanitz appeals to the crucial issue which remains valid to this day: the specificity of the artistic development in the Balkans, where the Byzantine tradition connects with the traits of the West, which he saw, above all, in the decoration of the Morava churches [22, vol. 1, pp. 627-632].

In general, the studies on Serbian medieval monuments in the $19^{\text {th }}$ century are usually limited to descriptions of the external appearance of the churches and their artistic qualities. The researches collected written historical evidence about the time and circumstances of the church appearance, recorded unique inscriptions preserved to that day, and made measurements and fixation drawings. Most importantly, they took urgent measures in order to save the ancient architectural heritage [34, pp.17-19]. However, the formation of the holistic concept of the history of Serbian architecture was still far off. The first attempts to generalize were reduced to dividing the Serbian architecture into two groups: the first one associated with Romanesque influence and the second one, starting in the $14^{\text {th }}$ century (which automatically included Morava) - with the Byzantine influence. Those influences were understood differently, as well as their manifestation and extent. Such an approach prevented the scholars from understanding the most important things, such as the main-content, the specificity and mechanisms of the development of Serbian architecture as a holistic phenomenon.

The critical study of Serbian medieval architecture started in the last decades of the $19^{\text {th }}$ century, when it gained the required amount of factual material, and when Serbian scholars began to apply modern European scientific methods to the exploration of their own architectural heritage. During that time they for the first time encountered the problem of accurate periodization and its logic: some of them raised the question of the need to see Serbian medieval architecture divided into several stages, due to cultural and political factors, while others talked about changing styles.

Among the representatives of that new generation we should, first and foremost, mention M. Valtrović, who received architectural education in Germany, but went down in history as the organizer and the leader of the systematic scientific study of the Serbian medieval architecture, sculpture and painting, the author of the "Project for the Protection of Antiquities", an academic, the member of the imperial archaeological societies of Moscow and Berlin, the director of the National Museum in Belgrade (since 1881), one of the founders of the Serbian archaeological society (1883), and the founder of the "Starinar" magazine (published since 1884) [9, p.297]. Together with his colleague and friend D. Milutinović, he surveyed several dozen ancient churches, including the Morava ones [9, p.511]. The data collected during those expeditions became the basis of the first scientific concept of the history of Serbian art; the concept which sought to identify the internal logic of the development of the ancient Serbian architecture taken as an original phenomenon, largely due to the ideology, historical and cultural identity of the Nemanjić and Hrebeljanović State [3; 41, pp. 123-124]. 
Medieval architecture of Serbia was divided by M. Valtrović now into three periods: that of Serbian Primorje (mid-12 $12^{\text {th }}$ - end of $13^{\text {th }}$ century), the "Byzantine period" (starts in the second half of the $14^{\text {th }}$ century) and "Morava period" (last quarter of the $14^{\text {th }}$ century -1459 ) $[63$, p. $4 ; 48$, p. 76]. The nine monuments in the Valley of the Morava created in the times of Prince Lazar and Despot Stefan Lazarević (Ravanica, Resava, Ljubostinja, Lazarica, Rudenica, Naupara, the old church at the Smederevo cemetery, Veluće and Kalenić) were referred to the last period. They stand close to each other not only geographically and chronologically, but, above all, in terms of stylistic traits, especially the structure and the nature of the decor [70, pp. 16-29; 63].

The author suggests that we look for the origin of those characteristics on Mount Athos, as well as in the Serbian art of preceding periods [64]. D. Milutinović quite mistakenly suggested that at the origins of that architectural tradition was one architect - Rade Borović, the author of the later church at Ljubostinja (ca. 1389) [15, pp. 25-26, 44; 59; 53, pp. 67-68], who perhaps was born in Primorje and who was close to Fra Vita from Kotor, the renowned master of the church at Dećani monastery [40, p. 256]. Thus, Milutinović tried to identify and explain the continuity of Morava school in relation to the traditions of the earlier Serbian architecture. In that way, even before the restoration of the most of monuments, M. Valtrović and D. Milutinović for the first time identified the Morava churches as a single group with the traits of regional particularities defined as the 'national style. The most important features of that style, determined by the work of specific masters, were vertically oriented dynamic compositions, decor and, most importantly, a special type of layout - a triconch plan. Analyzing the issue of the ratio between the Western and Byzantine elements, they began to consider the development of Serbian architecture not as the succession of foreign influences, but as a single process with different interlinked phases.

These courses of the studying of the Morava monuments remain relevant today. The concept of Valtrović and Milutinović could be recognized as practically flawless, if the architecture of the Morava style was really limited to the monuments that had been already reviewed ${ }^{2}$, and if the line of studying Serbian architecture as a single process was followed up and thoroughly argued.

Following Valtrović, other researchers considered the Morava churches as a separate group of monuments united by common stylistic and typological characteristics. On the one hand, there were attempts to expand that group. For instance, A. Stevanović [54] includes a larger number of monuments into the Morava group and for the first time raises the question of the possibility of earlier dating than the times of Prince Lazar. On the other hand, there are also opposing views on that issue.

For example, P. P. Pokryshkin offered a version of the chronology that considers the Morava chuches as a result of the activities of one workshop which began its work only at the turn of the $14^{\text {th }}-15^{\text {th }}$ centuries under the leadership of Rade Borović, and which adopted the triconch plan from the architecture of Thessaloniki (the Church of the Prophet Elijah). Pokryshkin defined the Morava monuments as the Byzantine style with distinct features of national identity and

2 The authors themselves understood that their review of the ancient Serbian church architecture was not complete [63]. 
greatly expanded the range of similarities among the monuments of late Byzantine architecture (Epirus, Trebizond, Veliko Tarnovo, Skopje) [46, pp.6, 59-73].

At present Pokryshkin's preposition that the Church of the Prophet Elijah could serve as a model for the Morava style triconch plan is not been accepted by the scholars because upon closer examination it is easy to see the significant differences between those monuments and the chronology is still debatable. Yet, the notion of the dominant role of the Byzantine tradition in the late medieval architecture of Serbia was further developed at end of the $20^{\text {th }}$ century.

However, in the first half of the $20^{\text {th }}$ century, another concept of the history of the Serbian architecture created by famous French byzantologist G. Millet for decades defined the development of the research in that area. In Serbia, G. Millet is primarily known as the author of the officially accepted periodization of the Serbian medieval architecture [38, pp. 152-158; 39; see also: 32]. Summarizing the research of his predecessors in accordance with the advanced at that time Western methods of scientific positivism, G. Millet created two fundamental theoretical statements: firstly, the possibility and the need for a strict classification and systematization of monuments, secondly, the understanding of the processes of architecture development as the evolution from simple forms to more complex ones.

Under these provisions, G. Millet suggested that Serbian medieval architecture is a sequential series of chronologically and geographically isolated 'schools': the 'school of Raška', the 'school of Byzantine Serbia' and the 'Morava school'. Noteworthy, the term 'school' in that case referred to the group of monuments with similar stylistic and typological characteristics; so 'style' and 'school' were considered as equivalent concepts. Herewith, the Raška style, according to G. Millet, formed under the decisive role of the Western European influences, whereas the latter, the Morava style, by contrast, was a result of the merger of the elements of the Byzantine architecture of Greece and Serbian traditions. But it is not clear what is the distinguishing feature of the 'school of Byzantine Serbia' which was selected as "residual" because the typological, stylistic and the regional diversity of architecture of this period does not allow us to determine any stylistic unity.

The monuments of the Morava school were distinguished by G. Millet on the basis of typological and stylistic uniformity, as well as territorial separation. Their main typological feature is the triconch plan, which is known in two basic versions: a single-nave church and a four-pillar cross-domed church with separately standing pillars. Highlighting these two varieties, Millet rightly connects one with the tradition of the Raška style, the other with the architecture of the Serbian-Byzantine period. At the same time, according to the scientist, the main feature of the Morava style churches - lateral conches - was borrowed by the Serbs on Mount Athos. This opinion, though not reasoned by any evidence, for the following generations became an axiom.

In regard to the other distinctive feature of the Morava churches, flat-reliefed stone décor, Millet's position is less certain. He calls Athos, Christian and Muslim East, Russia, Caucasus, and partially Western Europe as its primary sources and illustrated manuscripts and textiles as intermediate links in the chain of alleged influences [39, pp. 150-153, 158-159, 181-191, 198]. Paying tribute to the typical for the first half of the $20^{\text {th }}$ century passion for theories about the dissemination of all kinds of influences, Millet nevertheless identifies and describes genuinely Serbian traditions in the typology of Morava style buildings. He does not ignore the existence of 
links between the three stages of the development of the Serbian architecture, but his proposed classification seems to be largely artificial and mechanistic.

In regard to the questions of chronology, Millet dates the Morava monuments to the times of Prince Lazar (1371-1389) and Despot Stefan Lazarević (1389-1427). In the absence of reliable written sources that would help with the dating of the majority of the monuments, the French researcher relies on the study of the dynamics of architectural development. In this process, the important place belongs to the analysis of the stone sculptural decoration. G. Millet offers a framework of the development from simple threads at an early stage to luxurious carved ornaments in later buildings that, as it seems, speaks in favor of gradual improvement of Morava school artists. Therefore the chronology becomes also the criterion of artistic value.

As a result, the sequence of the construction of the churches was determined by G. Millet basing on the line of Morava school development created by him: from the Old church at the cemetery in Smederevo to Ravanica and Lazarica, which, in turn, were seen as models for Veluće, Naupara, etc. [39, pp.152-191]. In this case, it is obvious that Millet's evolutionary hypothesis doesn't work as late dated monuments actually were the first ones, and vice versa. Such errors are very revealing, and it would be wrong to ignore them. There are other serious shortcomings in Millet's classification. For instance, a number of the Morava style triconches fall out of his general plan. They are put into the "exceptions" group because they do not contain the second character, according to Millet, - the specific decor of facades. Meanwhile, the particularly significant in historic, sacral, and artistic terms monuments, such as Resava, Sisoevac, Vračevšnica, Pavlovac, as well as many others, fall under the exception [39, pp. 191-198].

Millet's classification, despite its imperfections, became a decisive event in the field of the study of Serbian medieval monuments and greatly influenced the fate of Serbian science of the $20^{\text {th }}$ century [6, pp.475-477; 9, p.496]. The collected materials and the scientific method applied by the French researcher were widely used by Serbian experts for further study in the second and third quarters of the $20^{\text {th }}$ century.

With regard to the problem of the Morava monuments, serious alternative views at that time were presented by J. Tatić and M. Vasić. The first one again raises the question of the earlier chronology and the origins of the Morava architecture [58]. M. Vasić [65] in his book "Lazarica and Ziča" tried to establish a holistic view on the Serbian medieval architecture, but on different grounds than it was suggested by G. Millet [52].

Vasić reviews two most prominent monuments of the starting and ending phases of the history of the Serbian medieval state in connection with cultural and historical processes, which, in his view, should help to disclose the contents of the architectural development process. He denies the possibility of applying any schema and periodization in principle and considers art as the infinite series of events, the appearance of which in each case depends on the variety of cultural and political factors which predetermine the heterogeneous character of the development and the infinite number of variants. The most important factors that predetermined the specificity of Serbian architecture, according to Vasić, were the State and the Church.

Following this logic, he explains the originality of the Morava monuments by the political situation during the reign of Prince Lazar, when the Serbian Church once again regained dominance, the prevalent internal ideology was hesychasm, and the leading role was played by monasteries. Criticizing Millet for the unfounded assumptions about the Athos origin of the 
side apses in the Morava churches, Vasić offered an alternative hypothesis. In his view, it is in Lazarica, a small church built inside the walled fortifications of the settlement, where the side conches first appeared added in order to accommodate the choristers. Before, side conches were not needed because in four-pillar church the choir could be placed in the arms of the cross. Thus, Lazarica is in the beginning of the chronological series of Morava monuments.

So, in the first third of the $20^{\text {th }}$ century, two fundamentally different approaches to the possibility of periodization of Serbian medieval art emerged. The approach proposed by Millet was certainly more methodologically developed and scientifically sound, but too mechanistic and evolutionary; it did not take into account regional specificities. In contrast to the method of "pure art history" that takes account of purely architectural aspects, typological and stylistic characteristics, there was a need to identify precisely Serbian cultural and historical specificity. However, at that time, this approach did not resulted in scientifically based results.

During the 1930-1970s, there was continuing identification and disclosure of the monuments of the Serbian medieval architecture. In these decades many previously unknown monuments (including small provincial) were introduced into scientific circulation and a lot of previously unknown information was clarified. A growing number of new data revealed more and more contradictions in Millet's scheme, but it remained commonly accepted. There were still many inaccuracies and stretches, but, in general, nothing changed in the understanding of the Serbian medieval architecture. Such authors as V.Petković [44], S. M. Nenadović [42, p. 157-189], and A. Deroko [14, pp. 175-239] continued to deal with some elected monuments that were shuffled in different combinations.

J. Bošković, who had been doing research survey and restoration of medieval churches, played a major role in the dissemination and adoption of Millet's concept, which he used as the basis for his book and for the section written by him in the "Universal History of Architecture" published in the USSR [5; see also: 8]. On the example of a few Morava churches he pointed out the diversity of style, typology, technology, design, and decor, as well as a large number of questionable datings. But in general the concept of Millet did not suffer any changes. He drew on the same periodization of the Serbian architecture and the same definition of the Morava school, without critical review, using a few notable designs which are included in survey work on Byzantine architecture, written in the 1960-1970s by R. Krautheimer [28, pp.433-440] and C. Mango [33, pp. 308-323].

After the World War II, the first attempt to fundamentally correct the chronology of Morava churches, explain their stylistic and typological diversity and find the origins of the primary unifying features, such as triconch planning scheme, was made. J.Stričević tried not only to link Morava monuments with a common historical and cultural context, but also to reveal their relationship with social, political and religious life, as well as some features of worship. Hence, he explained the presence of two types of plans within the Morava school: single-nave churches, he called courtiers 'zadužbina', and four-pillared, monastery ones [57].

However, in the 1950s, there was no possibility to confirm that generally reasonable hypothesis and it did not gain any recognition. The circumstances of the churches building ant their initial purpose still constitute an equally important problem as their chronology. Stričević traditionally linked the side conches of the Morava churches with Athos. Not confining with mere assertion, he sought to identify the causes and mechanisms of borrowing of that scheme, 
which again he saw in political and church history. As a possible mediator in the transferring of triconch plan from Athos on Serbian territory Stričević considered Elder Isaiah while the first Moravian buildings he connected with Macedonian triconches (the Church of St. Archangel in Kučevište and the church in Rdjavac), which provided an opportunity for the earlier dating of the first Morava monuments (middle and the third quarter of the $14^{\text {th }}$ century). Thus, Stričević was the first one to raise such critical issues as the chronology of the Morava monuments, as well as territorial cohesion and consistency of processes in the Macedonian and Morava region.

The opinion of Stričević on the development of the Morava church type and the possibility of early dating was not accepted B. Vulović, the author of another important study on the subject in the 1950s and 1960s. In his monograph "Ravanica" [67] written after the extensive restoration work, he for the first time claims that this Prince Lazar's monument is to be put in the beginning of the chronology of the Morava monuments. According to Vulović, the main condition for the formation of the original traits of the Morava churches is the favorability of political, ideological, and economic factors during the reign of Prince Lazar. The existence of long-standing and close ties between Serbia and Athos, and especially the reconciliation of the Serbian patriarchate with Constantinople, which occurred in the 1370s under Lazar, the author considered as sufficient arguments to confirm the version of the Athos origin of the side apses. He suggested that the Serbs focused primarily on the very few fragments of the katholikon of the Hilandar monastery, built by king Milutin in the first quarter of the $14^{\text {th }}$ century, the forms of which were creatively connected with the best examples of cross-domed five-headed churches of the same era (the Virgin Ljeviška, Staro-Nagoričino, Gračanica) [68]. It gave as the result a new type of church building, the finest example of which was Ravanica.

B. Vulović made a great contribution to the study of another important feature of the Morava churches - the decor. This feature was highlighted by researchers of the late $19^{\text {th }}-$ early $20^{\text {th }}$ century. At that time, relief and polychrome decoration of the facades of the Morava churches, usually considered a result of external influences, offered a wide variety of sources: Croatian and Zeta littoral, Western Europe, Byzantium, Mount Athos, Armenia, Georgia, Christian and Muslim East, even Ancient Rus. B. Vulović notes that such conclusions in most cases were made without a detailed study of both the features of the stone plastic and the processes within the Serbian artistic environment. He proposes to consider decorative programs of facades of Moravian churches in connection with the features of three-dimensional and structural solutions in Serbian architecture of the time [68, pp.92, 95; 69, pp. 25-26]. From his point of view, the decor of the Morava churches is not the result of eclectic borrowing of diverse elements, but a kind of embodiment of common for the late Byzantine art trends. Later Jovanka Maksimović [30, pp. 117-152; 31]. and Nadežda Katanić [24] summed up the opinions of their predecessors and showed the complexity of the study of that issue, on which there would be no consensus.

As J.Stričević, B. Vulović saw a problem in the prevailing periodization of the Serbian medieval architecture, which became particularly evident after the restoration of monuments, the disclosure of numerous new buildings, clarification of the circumstances of their construction. Many facts did not fit in the old schema. Instead of territorial and chronological principles underlying Millet's periodization, Vulović suggested considering interrelated historical and cultural periods and talked about the impact of economic and political factors on the art of these periods. 
The term 'Morava school' he replaces with descriptive names, such as "Morava group of monuments" or "the architecture of Prince Lazar and his heirs epoch". However, the writings of Vulović depart from the 'universal' Western style classifications toward studying the specifics of regional areas, even though this way only scheduled.

The important contribution to the study of Morava churches was made by an outstanding researcher of the Serbian and Byzantine architecture, Vojislav Korać [25, pp. 157-168; 26; 27]. From his point of view, the Morava school is a very conditional term, because its perfect embodiment is found only in a few monuments of the Prince Lazar period, and in each case - in different ways. In general, it is a striking and original trend in architecture which is distinguished by specific parameters: the plan, volume-spatial composition, design, construction technique, figurative and polychrome decor. The main feature of the Morava churches is typical triconch plan in a compressed or advanced (with four pillars) option, coupled with a Byzantine dome-type church. All other features, including flat-relief decor (which is very rare for Morava monuments, as Korać emphasizes) have Byzantine origins.

These features are used in various combinations, so there are many significant differences between the monuments. This variety of options does not fit into Millet's ideal scheme. Korać comes to the conclusion that the architecture of the era of Prince Lazar and his heirs is different from the architecture of the past decades, with which it is inextricably linked, due to the spread of some of the latest trends of the late Byzantine era in general. From the Byzantine architecture of the late Paleologian period, the Morava school is distinguished only by greater freedom of creativity of local Serbian masters, which is particularly evident in the decoration of churches and in the methods of vertical organization of the composition, to which were added side apses borrowed on Mount Athos. The last assertion is introduced by Korać without detailed reasoning, simply on the basis of the stability of the application of side apses on Mount Athos and in Moravian Serbia. Korać considers the Serbian architecture of the late $14^{\text {th }}-$ first half of the $15^{\text {th }}$ century as one of the regional variants of the late Paleologian tradition and relates it with the architecture of Mystras, Nessebar, etc.

In the 1990s, the research on Morava churches was in crisis [27, pp. 209-210]. The use of the term "Morava school" introduced by G. Millet as referring to a certain stylistically united group of monuments was in contradiction with the results of many years of research. The careful study of archaeological and historical aspects gave a confident justification for the increase in the number of monuments belonging to the last period of the development of Serbian architecture, which was found earlier in the studies of V. Petković [44], J. Bošković [7, pp. 211-214], S. Nenadović [42, pp.157-189], A. Deroko [14, pp. 177-179] $]^{3}$. The variants of the realization of the ideal Morava scheme identified and described by V. Korać and other scholars or, more precisely, deviations from it (including churches without any side conches [49]) made obvious the lack of stylistic unity. The answer to the question about the origins of this regional trend was also not given, although its connection with the previous traditions was no longer in doubt. This, in turn, leads to a blurring of the chronological boundaries and requires a revision of the dating of many monuments.

3 A. Deroko increased an amount of Morava monuments adding of Skadar monuments and Dobrun. Thus he changed the territorial boundaries of the Morava school. 
Vladislav Ristić, the author of the first and so far the only monograph on this topic, tried to solve the problems accumulated in the study of the Morava architecture [50]. He agrees with Vulović and Korać that most fully Moravian style manifested itself in Lazarica and Ravanica. Although Vulović and Korać put these monuments at the beginning of the line of Morava monuments, according to Ristić, they had to be preceded by a certain path of development. Ristic questions the possibility of the influence of the architecture of Byzantium, the Serbian Primorje, and the West of that time on the Morava architecture. Not always offering sufficient evidence, he tries to legitimize the early dating of some of the Morava monuments proposed by his predecessors, especially Stričević.

According to Ristić, the architecture of Kosovo, Metohija and Macedonia for a long time was influenced by the Athonite tradition that led there to the emergence of triconches already in the 1320-1340s (the church of the Rila monastery, the church of the Virgin in Lešje, the church of St. Nicholas at Mrač, the church of St. Nicholas of the Archangels monastery near Prizren, the church in Rdjavac (Ubojac), the Church of St. Archangels in Kučevište [50, pp. 4950]). These he refers to as "proto-Morava" and considers them as the prototypes of the later Morava churches (four-pillar, single-naved, and simplified). From Ristić point of view, the term "Morava school" should be abandoned and replaced by three others, corresponding to the new periodization proposed by him. Triconches of the 1320s - 1340s in non-Morava territories, he proposes to call "pre-Morava". Then there is a group of "early Morava" triconches located on the Morava territories attributable to the period between 1350 and 1389. Finally, he proposes to refer to the architecture of 1389-1459 as "late Morava" and to consider each area separately. Thereby, Ristic revised the terminology, history, and the very structure of the old periodization and classification separating the concept of the "Morava period" and "Morava territory".

Unfortunately, not all hypotheses and logical constructions of Ristić are reasoned and satisfactory. The next step and, in fact, the main task of his work was an attempt to build a chronological series of monuments - an impossible task in the absence of an objective opportunity to clarify the dating of many of them. Like Millet, Ristić sees architectural development as the evolution of stylistic features. He chooses the ratio of the length and width of the church naos (i.e. elongation along the East-West axis which gradually increases from earlier to later monuments) as the main criterion for his evolutionary-chronological line. The possibility of such a pattern has not been confirmed.

Despite the groundlessness of the new evolutionary theory, the reliance on unverified facts and the lack of argumentation, Ristićs work still became an important contribution to the study of Morava architecture. He collected and summarized all the work of his predecessors, compiled the latest and most complete catalogue of the Morava churches (eighty eight of them) accompanied by exhaustive bibliography [50, pp. 209-234], and proposed to revise many questions the study of Morava architecture could not move on without. Such positions of Ristic as the rejection of the concept of 'school' and the need to expand the chronological boundaries of Morava architecture can be accepted. If the satisfactory answers to all raised questions have not been found, this should be done in the future. First of all, an interesting hypothesis of Ristić on the development of the triconch type as early as the Imperial period for the Macedonian and Kosovo-Metohija territories requires confirmation through the in-depth research of the architectural, historical, and cultural contexts. 
However, the complex studies that could provide an alternative to the work of Ristic have not yet been published. There were several monographs and articles on Morava architecture, among which we should highlight the work of Ivan Stevović, his monograph on Kalenić and the article "Architecture of Morava Serbia: Local School of Architecture or the Epilogue of the Main Currents of Late Byzantine Architecture" [55; 56]. They criticize the clearly outdated artificial periodization of Millet and the latest evolutionary scheme of Ristić which is based on unverified data. Stevović believes that the concept of 'school' does not apply to Serbian architecture and generally opposes any rigid schemes. His main task is to show the Byzantine origin of all Serbian architecture from the beginning of the $14^{\text {th }}$ century to the end of the Morava period. Stevović proposes to return to the concept of Korać, which gives a convenient definition of Morava architecture, which frees from the boundaries of the style conventions. It also allows to explain the individual elements of Morava monuments with the variety of late Byzantine arsenal of architectural forms and means, and to interpret the general processes as a wide framework of eclectic logic, where they will always find a place on a par with other regional options, such as the architecture of Epirus, Thessaloniki, Mystras, Nessebar, and even withering Constantinople.

Slobodan Ćurčić who studied not only Serbian architecture, but also Byzantine, in his latest work of 2010 on the architecture of the Balkans [13, pp.671-682], has rightly noted that the G. Millet's familiar term "Morava school" really is a smokescreen behind which a number of serious unresolved issues hides. First, it is a question of stylistic unity of the monuments created in the last quarter of the $14^{\text {th }}$ - the first half of the $15^{\text {th }}$ century on the greatly reduced territory of the Serbian state; secondly, the emergence of rich stone carving in the decor of these churches; thirdly, the unity of the plans reflecting the influence of the Athos architecture on the Serbian one. Curčić notes that the decision was too narrow and too rigid. From his point of view, the same problems related to both planning schemes and style affect a much larger range of monuments in the larger areas. The spontaneous emergence of the Morava school as the initiative of one customer - Prince Lazar is another myth, continues Curčić [13, p.671]. Paying tribute to the importance of Prince Lazar's role, the researcher believes that the construction of some buildings was attributed to him without reason. The researcher notes the presence of other problems in the study of Morava architecture. On the similarity between the magnificent decor of Morava churches and the late Byzantine and late Gothic monuments, there has been written a lot, but still this issue has not received a systematic study. Little attention has been paid to the possibility of various masters and builders teams moving from place to place, which could help to clarify these and other issues. Still there is no explanation of the fact that in the last quarter of the $14^{\text {th }}-$ first half of the $15^{\text {th }}$ century the new style incorporated a lot of conservative elements. However, Curčić distances himself from those of his predecessors who viewed the Morava school as a national phenomenon, and regards it as the last flowering of Byzantine architecture, which took place on the territory of Serbia and under the protection of its rulers.

S. Curčić tried to answer some of the questions and to highlight the role of the architecture of the preceding period in the genesis of the "Morava school". He identified a number of buildings of the second and third quarters of the $14^{\text {th }}$ century in the vicinity of Skopje, in which, on the one hand, there are features of Byzantine architecture, on the other hand, undoubtedly the influence of traditional architecture of Serbian Primorje [11; 12, pp.60-62, 67-68; 13, pp. 636644; 682]. According to S. Curčić, this trend was dominant in the Serbian architecture of the 
mid - third quarter of the $14^{\text {th }}$ century, and by 1370 it transformed into a new style called the "Morava school" [12, pp.60-62, 67-68, nt. 89]. However, S. Ćurčić does not give a detailed analysis on the specific manifestations and ways of this process.

His follower Elena Bogdanović [2] has recently conducted a thorough study of monuments in the Skopje area, which she also considers the previous stage for the development of architecture of the Morava period. She has conducted a more detailed analysis of the composition, style and technical features of these buildings, but the relationship with the Morava churches was only outlined at the level of similarity of individual parameters.

The student of S. Ćurčić, E. Trkulja, developed another trend in the study by analyzing the facade decoration of late Byzantine churches [62]. Considering the Serbian architecture of the second half of the $14^{\text {th }}$ - first half of the $15^{\text {th }}$ century with the architecture of Epirus, Thessaloniki, Asia Minor, Constantinople and Bulgaria, the researcher emphasizes the common trends in the development of the facade decoration and believes that in the "Morava school" late Byzantine trends found their most complete embodiment. The study of other problems related to Morava architecture was not included in the objectives of this work. The recently announced project under the guidance of S. Ćurčić entitled "Corpus of Ecclesiastical Architecture of Serbia of the Late Middle Ages, 1355-1459" [47, p.7] not only combines the monographs of Curčić and S. Popović about Naupara, it is important for us because of the change in the accepted periodization of the architecture of Morava Serbia. After Ristić, S. Curčić and S. Popović consider the period of the collapse of the Empire of Dušan (1355-1371), which they view as a direct introduction to the Morava period. The emergence of such a new area of research is welcome.

Along with that, during the research on the Churches of St. Archangels in Kučevište [61, pp. 173-184] and the church in Rdjavac (Ubojac) village [60, pp. 67-88] B. Todic suggested later dating ( $16^{\text {th }}$ century) for those two triconches which had been considered as the direct predecessor of Morava monuments on Macedonian territory and dated to the 1330s.

Thus, if Todic was right, there is no clear, reliable evidence of the existence of prototypes of Morava triconches during the period of the collapse of the Empire and before the transition of political centers into the Morava region.

At the moment, it became clear that as a definition of the last period of Serbian architecture, the term "Morava school" is ambiguous and hardly applicable, because among the monuments of this era there is no clear unity of style, and almost nothing is known about the conditions of their construction and masters. The dating of monuments of Morava architecture, its periodization, the origins of the main architectural features, the nature of the links with the architecture of previous periods - all these problems have received different interpretations of hypothetical nature. The problem of the emergence of the triconch type and the meaning of side conches of Morava churches also requires special attention. All these questions remain unclear until now and require a comprehensive study.

\section{References}

1. Belov M. V. U istokov serbskoi natsional'noi ideologii: mekhanizmy formirovaniia i spetsifika razvitiia (konets XVIII - seredina 30-kh gg. XIX veka) At the Origins of the Serbian National Ideology: The Mechanisms of Formation and the Specifics of Development (the End of the $18^{\text {th }}-$ the Middle of the 30s of the 19 $9^{\text {th }}$ Century). Saint Petersburg, Aleteiia Publ., 2007. 544 p. (in Russian). 
2. Bogdanović J. Regional Developments in Late Byzantine Architecture and the Question of 'Building Schools': An Overlooked Case of the Fourteenth-Century Churches from the Region of Skopje. Byzantinoslavica, 2011, vol. 69/1-2, pp.219-266.

3. Bogdanović S. Mihailo Valtrović and Draguti Milutinović as Researchers of Serbian Antiquities. Izlozi Srpskog učenog društva. Belgrade, 1978, pp. 29-36 (in Serbian).

4. Bogdanović S. Franc Mertens and Serbian Medieval Architecture. Zbornik za likovne umetnosti (Proceedings of Fine Arts), no. 15. Novi Sad, 1979, pp. 207-226 (in Serbian).

5. Boshkovich D. The Architecture of Serbia and Macedonia. Vseobschaia istoriia arkhitektury (The Universal History of Architecture), vol. 3. Leningrad; Moscow, Stroiizdat Publ., 1966. pp.418-464 (in Russian).

6. Bošković Đ. Gabrijel Mije and Serbian Medieval Monuments. Srpski književni glasnik (Serbian Literary Journal), 1935, no. 46-6, pp. 475-477 (in Serbian).

7. Bošković Đ. Osnovi srednjevekovne arhitekture (Basics of Medieval Architecture). Belgrade, 1947. (in Serbian).

8. Bošković Đ. On Our Architecture of the Middle Ages in the Moscow Publication “The Universal History of Architecture", Starinar, 1968, no. 18, pp. 225-231 (in Serbian).

9. Ćirković S.; Mihaljčić R. Enciklopedija srpske istoriografije (Encyclopedia of Serbian Historiography). Belgrade, Knowledge Publ., 1997. XV, 741 p. (in Serbian).

10. Curčić S. Articulation of Church Façades during the First Half of the Fourteenth Century. Vizantijska umetnost početkom XIV veka. Naučni skup u Gračanici (Byzantine Art at the Beginning of the $14^{\text {th }}$ Century. Scientific Conference in Gračanica). Belgrade, 1978, pp. 17-27.

11. Ćurčić S. The Architectural Significance of the Hilandar Kafolikon. Fourth Annual Byzantine Studies Conference. Abstracts of Papers. Ann Harbour, University of Michigan Publ., 1978, pp. 14-15.

12. Ćurčić S. Architecture in the Byzantine Sphere of Influence around the Middle of the Fourteenth Century. Dečani i vizantijska umetnost sredinnom XIV veka. Medunarodni naučni skup povodom 650 godina manastira Dečana. Septembar 1985 (Dechany and Byzantium Art of the Mid. 14th Century. Materials of the International Conference Dedicated to the 650th Anniversary of Dechany Monastery. September, 1985). Belrade, Jedinstvo Publ., 1989, pp.55-68.

13. Curčić S. Architecture in the Balkans from Diocletian to Suleyman the Magnificent (ca. $300-c a .1550)$. London; New Haven, Yale University Press Publ., 2010. 914 p.

14. Deroko A. Monumentalna i dekorativna arhitektura u srednjevekovnoj Srbiji (Monumental and Decorative Architecture in Medieval Serbia). Belgrade, Turistička štampa Publ., 1985 (in Serbian).

15. Đurić V. J. Church of St. Peter in Bogdašić and Its Frescoes. Zograf, 1985, vol. 16, pp.31-36. (in Serbian).

16. Förster L. Die Baukunst der Kirchen und Klöster im Orient: Allgemeine Bauzeitung 22. Wien, L. Försters artistische Anstalt Publ., 1857. (in German).

17. Jovanović M. Austrian Architect Ludwig Förster as a Writer on Byzantine and Serbian Churches. Saopštenja (Announcements), 1985, vol. 17, pp. 213-218.

18. Kadijević A. Jedan vek traženja nacionalnog stila u srpskoj arhitekturi (sredina XIX - sredina XX veka) (A Century of Searching for a National Style in Serbian Architecture (mid $19^{\text {th }}-$ mid $20^{\text {th }}$ Century). Belgrade, Građevinska knjiga Publ., 1997. 387 p. (in Serbian).

19. Kanitz F. Serbiens Byzantinische Monumente. Wien, Hof-\& Staatsdruckerei Publ., 1862. 27 p. (in German).

20. Kanitz F. Serbien. Historisch-ethnographische Reisestudien. Leipzig, H. Fries Publ., 1868. 744 p. (in German).

21. Kanitz F. Das Königreich Serbien und das Serbenvolk von der Römerzeit bis zur Gegenwart: Land und Bevölkerung. Leipzig, Bernhard Meyer Publ., 1909. 594 p. (in German).

22. Kanitz F. Serbia: Zemlja i stanovništvo (Serbia: Land and Population). vol. 1-2. Belgrade, Srpska književna zadruga Publ., 1985 (in Serbian).

23. Karadžić V.S. Geografičesko-statističesko opisanije Srbije (Geographical and Statistical Description of Serbia). Belgrade, 1826-1828 (in Serbian).

24. Katanić N. Dekorativna kamena plastika Moravske škole (Decorative Stone Plastics of the Morava School). Belgrade, Prosveta Publ., 1988. 266 p. (in Serbian).

25. Korać V. Les origines de lécole de la Morava. Moravska škola i njeno doba: naučni skup u Resavi 1968 (Morava School and Its Age: Scientific Conference in Resava 1968). Belgrade, Filozofski fakultet, Odeljenje za istoriju umetnosti Publ., 1972, pp. 157-168 (in French).

26. Korać V. Sources of Moravian Architecture. Između Vizantije i Zapada:Odabrane Studije o Arhitekturi (Between Byzantium and the West: Selected Studies on Architecture). Belgrade, Prosveta Publ., 1987, pp. 131144 (in Serbian). 
27. Korać V. Monumental Architecture in Byzantium and in Serbia in the Last Century of Byzantium. Features of the Facade Decoration. Zbornik radova Vizantološkog instituta (Proceedings of the Byzantine Institute), 2006, no. 43, pp. 209-213 (in Serbian).

28. Krautheimer R. Early Christian and Byzantine Architecture. $4^{\text {th }}$ ed. (revised by R. Krautheimer and S. Curčić). New Haven, London, Yale University Press, The Pelican history of art Publ., 1986. 553 p.

29. Magarasević Đ. Putovanje po Srbiji u 1827 godine (Travel to Serbia in 1827). Belgrade, Prosvets Publ., 1983. 321 p. (in Serbian).

30. Maksimović J. Srpska srednjovekovna skulptura (The Serbian Mediaeval Sculpture). Novi Sad, Matica Srpska Publ., 1971. 188 p. (in Serbian).

31. Maksimović J. Moravian Sculpture. Moravska škola i njeno doba: naučni skup u Resavi 1968 (Morava School and Its Age: Scientific Conference in Resava 1968). Belgrade, Filozofski fakultet, Odeljenje za istoriju umetnosti Publ., 1972, pp. 181-188 (in Serbian).

32. Mal'tseva S. V. About Some Problems of Division into Periods of Serbian Medieval Architecture. A Term Is Moravian School. Iskusstvoznanie (Art Studies), 2012, no. 3-4, pp.95-116 (in Russian).

33. Mango C. Byzantine Architecture. New York, Harry N. Abrams Publ., 1976. 382 p. (in German).

34. Medaković D. The First Trials of Antiquities in Serbia. Istraživači srpskih starina (Researchers of Serbian Antiquities). Belgrade, Prosveta Publ., 1985. C. 154-157 (in Serbian).

35. Mertens F. Etwas über Serbien. Berliner Kalender für 1847. Jahrgang 21. Berlin, Karl Reimarus Publ., 1847 (in German).

36. Mihaljčić R. Prince Lazar and the Restoration of the Serbian State. O knezu Lazaru: Naučni skup u Kruševcu 1971 (Prince Lazar: Scientific Conference in Kruševac 1971). Belgrade, Naučno delo Publ., 1975, pp. 1-11 (in Serbian).

37. Mihaljčić R. Lazar Hrebeljanović: istorija, kult, predanje (Lazar Hrebeljanović: History, Cult, Tradition). Belgrade, Bigz Publ., 1989. 378 p. (in Serbian).

38. Millet G. L'École grecque dans l'architecture byzantine. Paris, Leroux Publ., 1916 (in French).

39. Millet G. Lancient art serbe. Les églises. Paris, E. de Boccard Publ., 1919. 208 p. (in French).

40. Milutinović D. Short Discussion at the Opening of the $5^{\text {th }}$ Exhibition of Photographs of Architecture, Painting and Sculpture 14 May 1878. Glasnik Srpskog učenog društva, 1879, vol.47, pp. 251-258 (in Serbian).

41. Misković-Prelević L. Catalogue of Drawings of Mihailo Valtrović and Dragutin Milutinović at the Historical Museum of Serbia. Izlozi Srpskog učenog društva. Belgrade, 1978, pp. 123-125 (in Serbian).

42. Nenadović S. M. Some questions on the Construction Techniques and Style of Portals in Medieval Serbian Architecture. Raška baština (Raška Heritage), 1980, vol. 2, pp. 43-69 (in Sebian).

43. Novaković S. Vaskrs države srpske: političko-istorijska studija o prvom srpskom ustanku 1804-1813 (The Easter State of Serbia: Political-Historical Study on the First Serbian Uprising (1804-1813). Belgrade, 1954 (in Serbian).

44. Petković V. Pregled crkvenih spomenika kroz povesnicu srpskog naroda (A Review of Church Monuments of the Serbian People). Belgrade, 1950 (in Serbian).

45. Pirh O. D. Putovanje po Srbiji u godini 1829 (Travel to Serbia in 1829). Belgrade, Prosveta Publ., 1983. 321 p. (in Serbian).

46. Pokryshkin P. P. Pravoslavnaia tserkovnaia arkhitektura XII-XVIII stoletii v nyneshnem serbskom Korolevstve (Orthodox Church Architecture of the $12^{\text {th }}-16^{\text {th }}$ Centuries in the Present Serbian Kingdom). St. Petersburg, Imperatorskaia Akademiia khudozhestv Publ., 1906. 76 p. (in Russian).

47. Popović S.; Curčić S. Naupara - korpus sakralne arhitekture Srbije u kasnom Srednjem veku 13551459 (Naupara - the Corpus of Sacred Architecture of Serbia in the Late Middle Ages 1355-1459). Belgrade, 2000 (in Serbian).

48. Radojćić S. Odabrani članci i studije 1933-1978 (Selected Articles and Studies 1933-1978). Belgrade; Novi Sad. Matice Srpska Publ., 1982. 346 p. (in Serbian).

49. Radulović E. A Group of Moravian Monuments without Side Conches. Kruševački zbornik, 1989, vol.4, pp. 47-78. (in Serbian).

50. Ristić V. Moravska arhitektura (The Morava Architecture). Kruševac, Narodni muzej Publ., 1996, 372 p. (in Serbian).

51. Šafarik J. Izvjestije o putovanju po Serbiji 1846 godine (Reports on Traveling to Serbia in 1846). L. Durković-Jakšić; M.Ž. Nikolić (ed.). Valjevo, 1993 (in Serbian).

52. Srejvović D.; Miloje M. Vasic, a Founder of Serbian Archeology. Starinar, 1984, vol.35, pp. 25-32. (in Serbian). 
53. Starodubtsev T. Srpsko zidno slikarstvo u zemljama Lazarevića i Brankovića (Serbian Wall Painting in the lands of Lazarevic and Brankovic), book 1-2. Belgrade, Univerzitet u Beogradu, Filozofski fakultet Publ., 2016 (in Serbian).

54. Stevanović A. Old Serbian Church Architecture and Its Significance. Srpski književni glasnik, 1903, vol. 9 (in Serbian).

55. Stevović I. Architecture of the Moravian Serbia: A Local Construction School or the Epilogue of the Leading Streams of the Post-Byzantine Architecture. Zbornik radova Vizantološkog instituta (Proceedings of the Byzantine Institute), 2006, no. 43, pp. 231-241 (in Serbian).

56. Stevović I. Kalenić. Bogorodičina crkva u arhitekturi pozdnovizantijskog sveta (Kalenić. The Church of Our Lady and Architecture of Late Byzantine World). Belgrade, Interprint Publ., 2006. 216 p. (in Serbian).

57. Stričević Ć. Two Variants of the Church Plans of the Moravian Architectural School. Zbornik radova Vizantološkog instituta (Proceedings of the Byzantine Institute), 1955, vol.3, pp. 213-219 (in Serbian).

58. Tatić Ž. Holy Archangels of Kučevište. Tatić Ž. Tragom velike prošlosti: Svetogorska pisma i monografske studije staree srpske arhitekture (Tracing the Great Past: Sanctuary Letters and Monographic Studies of the Old Serbian Architecture). Belgrade, 1929, pp. 175-189 (in Serbian).

59. Todić B. The Time of Raising and Painting in Ljubostinje. Saopštenja, 2007, vol. 39, pp. 101-115 (in Serbian).

60. Todić B. Monastery Ubožac. Kosovsko-metohijski zbornik, 2013, vol. 5, pp.67-88 (in Serbian).

61. Todić B. When the Holy Archangels Were Built near Kučevište. PATRIMONIUM. MK Spisanie za kulturnoto nasledstvo spomenici, restavracija, muzei (PATRIMONIUM. MK List of Cultural Heritage Monuments, Restoration, Museums), 2013, no. 11, pp. 173-184 (in Serbian).

62. Trkulja J. Aesthetics and Symbolism of Late Byzantine Church Facades, 1204-1453, Ph. D. dissertation. Princeton University, 2004.

63. Valtrović M. A View on the Old Serbian Church Architecture. Glas SKA (Bulletin of Serbian Royal Acade$m y), 1889$, vol. 17, pp. 3-39 (in Serbian).

64. Valtrović M. Kalenic. Starinar, 1907, vol. 1, part 2, pp.33-43 (in Serbian).

65. Vasić M. Žiča i Lazarica. Studije iz srpske umetnosti srednjeg veka (Žiča and Lazarica. Studies in Serbian Art of the Middle Ages). Belgrade, Izdavačka knjižarnica Gece Kona Publ., 1928. 256 p. (in Serbian).

66. Vujić J. Joakima Vujića, slaveno-serpskog spisatelja Putešestvije po Serbiji vo kratce sopstvennom rukom njegovom spisano u Kragujevcu u Serbiji (By Joakim Vujic, a Serbian Writer, Travels in Serbia, Briefly Written with His Own Hand in Kragujevac, Serbia). Budim Grad, 1828 (in Serbian).

67. Vulović B. Ravanica. Its Place and Contribution in the Sacred Architecture of Morava. Saopštenja, 1966, vol. 7. 215 p. (in Serbian).

68. Vulović B. The Role of Hilandar and Serbian Tradition in the Formation of Moravian Style. Moravska škola i njeno doba: Naučni skup u Resavi 1968 (The Morava School and Its Time: Scientific Conference in Resava 1968). Belgrade, Naučno delo Publ., 1972, pp. 169-178 (in Serbian).

69. Vulović B. Architecture of Ravanica. Manastir Ravanica: Spomenica o šestoj stogodišnjici (Ravanica Monastery: To the $600^{\text {th }}$ Anniversary of the Jubilee). Belgrade, Prosveta Publ., 1997 (in Serbian).

70. Waltrowits M. O Prodromos: Mitteilungen über neue Forschungen auf dem Gebiete serbischer Kirchenbaukunst. Wien, Lehmann \& Wentzel Publ., 1878. 23 p. (in German).

Title. Historiography of the Morava Architecture: Controversial Points of the Study.

Author. Mal'tseva, Svetlana Vladislavovna - Ph. D., head lecturer. Saint Petersburg State University, Universitetskaia nab., 7/9, 199034 St. Petersburg, Russian Federation; senior researcher. Research Institute of the Theory and History of Architecture and Town Planning (branch of the Central Institute for Research and Design of the Ministry of Construction of Russian Federation), Dushinskaia ul., 9, 111024 Moscow, Russian Federation.s.maltseva@spbu.ru

Abstract. Based on the historiographic material the article is addressed to the main problems in the study of the Serbian Morava architecture.

In the $19^{\text {th }}$ century the first critical research of the Serbian architecture placed it between the East and the West, formed certain approaches, and indicated some of the key issues influencing the study of the monuments of the Morava region.

In the beginning of the $20^{\text {th }}$ century the definition of the Morava architecture was given by G. Millet who puts it in the ending of the proposed by him periodization of the Serbian medieval architecture seen as the array of separate 'schools' divided chronologically and geographically. G. Millet identifies the monuments of the 'Morava school' relying on the typological and stylistic uniformity, as well as territorial separation. Their main 
typological feature is the triconch plan, which exists in two basic versions: a single-nave church or a four-pillared cross-dome church with separately standing pillars. Millet's view on the specifics and chronology of the 'Morava School' up to now continues to exist as the base view on the history of Serbian architecture. However, further findings and the studying of the monuments accumulated a number of issues which destroyed the harmony the original concept. The subsequent study of the Morava architecture once again raised the questions of the chronology of the monuments, their relationship to Byzantine and earlier Serbian traditions, as well as the extent and the nature of Western influences. Even the issue of the origin of such a bright typological feature as the triconch plan is still controversial.

At the moment, it became clear that as a definition of the last period of the Serbian medieval architecture, the term 'Morava school' is hardly unambiguous and applicable, because there is no clear stylistic unity among the monuments of that era and no information neither about the terms of their construction, nor the craftsmen involved in it.

In our view, the topics of the content, specifics, and mechanisms of the formation and evolution of the Serbian Morava architecture as an integrated regional phenomenon are to be put into foreground of modern research.

Keywords: Serbian medieval architecture; Morava architecture; Morava school; Byzantine architecture; triconch.

Название статьи. Историография сербской моравской архитектуры и спорные вопросы её изучения.

Сведения об авторе. Мальцева Светлана Владиславовна - кандидат искусствоведения, старший преподаватель. Санкт-Петербургский государственный университет, Университетская наб., д.7/9, Санкт-Петербург, Российская Федерация, 199034; старший научный сотрудник. Филиал ФГБУ «ЦНИИП Минстроя России» НИИТИАГ РААСН, ул. Душинская, д. 9, Москва, Российская Федерация, 111024. s.maltseva@spbu.ru

Аннотация. В данной статье мы постарались выявить основные проблемы изучения архитектуры Моравской Сербии на материале историографии.

Уже первые исследователи XIX в. помещают эту архитектурную традицию между Востоком и Западом и обозначают ряд ключевых вопросов, актуальных до сих пор.

В начале XX в. Г. Милле предложил периодизацию сербского средневекового зодчества в виде последовательного ряда хронологически и территориально обособленных «школ». Последняя из них «моравская школа» - была выделена на основании типологической и стилистической однородности, а также территориальной обособленности небольшой группы памятников. Их главная типологическая особенность - план в виде триконха, существующий в двух основных вариантах: однонефного храма и четырехстолпного крестовокупольного с отдельно стоящими опорами.

Сформулированные Милле положения о специфике и хронологии «моравской школы» в целом до сих пор сохраняются в качестве базовых для истории сербского зодчества. Однако дальнейшее раскрытие и изучение памятников во второй половине XX в. поколебало стройность первоначальной концепции, чем дальше, тем больше возникало вопросов о хронологии памятников, их соотношении с византийской и предшествующей сербской традициями, а также о степени и характере западных влияний. Даже проблемы происхождения такой яркой типологической особенности, как план в виде триконха, до сих пор оказываются дискуссионными.

На данный момент стало ясно, что в качестве определения последнего периода развития сербского зодчества термин «моравская школа» едва ли применим, поскольку среди памятников этой эпохи нет четкого стилевого единства, а об условиях их возведения и мастерах практически ничего не известно.

На первый план, на наш взгляд, сегодня выходят темы содержания, специфики, а также механизмов сложения и развития сербской моравской архитектуры как целостного регионального явления.

Исследование выполнено за счет средств Государственной программы РФ «Развитие науки и технологий» на 2017-2018 годы в рамках Плана фундаментальных научных исследований Минстроя России и РАACH, тема 1.2.32./1.2.46.

Ключевые слова: сербская средневековая архитектура; моравская архитектура; моравская школа; византийская архитектура; триконх. 